\title{
Cloning and Characterization of a Cyclic Peptide Synthetase Gene from Alternaria alternata Apple Pathotype Whose Product Is Involved in AM-Toxin Synthesis and Pathogenicity
}

\author{
R. D. Johnson, ${ }^{1}$ L. Johnson, ${ }^{1}$ Y. Itoh, ${ }^{3}$ M. Kodama, ${ }^{1}$ H. Otani, ${ }^{2}$ and K. Kohmoto ${ }^{1}$ \\ ${ }^{1}$ Laboratory of Plant Pathology, Faculty of Agriculture, Tottori University, Tottori 680, Japan; \\ ${ }^{2}$ United Graduate School of Agricultural Sciences, Tottori University, Tottori 680, Japan; \\ ${ }^{3}$ Faculty of Science, Shinshu University, Matsumoto 390, Japan \\ Accepted 8 March 2000.
}

\begin{abstract}
Alternaria alternata apple pathotype causes Alternaria blotch of susceptible apple cultivars through the production of a cyclic peptide host-specific toxin, AM-toxin. PCR (polymerase chain reaction), with primers designed to conserved domains of peptide synthetase genes, amplified several products from $A$. alternata apple pathotype that showed high similarity to other fungal peptide synthetases and were specific to the apple pathotype. Screening of a Lambda Zap genomic library with these PCR-generated probes identified overlapping clones containing a complete cyclic peptide synthetase gene of $\mathbf{1 3 . 1} \mathrm{kb}$ in length with no introns. Disruption of this gene, designated AM-toxin synthetase (AMT), by transformation of wild-type $A$. alternata apple pathotype with disruption vectors resulted in toxinminus mutants, which were also unable to cause disease symptoms on susceptible apple cultivars. AM-toxin synthetase is therefore a primary determinant of virulence and specificity in the $A$. alternata apple pathotype/apple interaction.
\end{abstract}

The genus Alternaria encompasses both nonpathogenic and pathogenic species. Included among the pathogens are many different pathotypes of A. alternata, each of which has a distinct and limited host range characterized by the production of host-specific toxins (HSTs) essential for pathogenesis (Nishimura and Kohmoto 1983; Kohmoto and Otani 1991; Otani et al. 1995). The mechanisms of host-selective pathogenesis are not well understood at the biochemical level, even in those cases where the toxin site of action is known. However, the participation of HSTs is an accepted model in plant pathology (Yoder 1980; Nishimura and Kohmoto 1983; Scheffer and Livingston 1984) and about 20 HSTs have been docu-

Corresponding author: R. D. Johnson; E-mail: rjohns19@wvu.edu

Current address of R. D. Johnson: Division of Plant and Soil Sciences, 401 Brooks Hall, West Virginia University, Morgantown 26506, U.S.A.

Nucleotide and/or amino acid sequence data for $A M T$ have been submitted to the DDBJ, GenBank, and EMBL data bases under accession number AF184074. mented (Walton 1996) of which at least nine are from A. alternata pathotypes (Otani et al. 1995). A. alternata (Fr.:Fr.) Keissl. apple pathotype (previously described as A. mali Roberts) produces the HST AM-toxin (Fig. 1), and causes Alternaria blotch, a disease of worldwide importance (Filajdić and Sutton 1991) and one of the most serious diseases of apple in Japan (Sawamura 1966), on a narrow range of susceptible apple cultivars (Kohmoto et al. 1974).

The chemical structure of AM-toxin has been elucidated (Okuno et al. 1974; Ueno et al. 1977) and consists of a fourmember cyclic depsipeptide (Fig. 1). Of the three derivatives, AM-toxin I (alternariolide) is the most abundant and cytotoxic. Both electron microscopy and physiological studies have identified two primary sites of action for this toxin: the chloroplast (Park et al. 1981) and the cell wall/plasma membrane interface (Park et al. 1977). In addition, HSTs, including AM-toxin, are known to suppress induction of host resistance (Pringle and Scheffer 1964; Hayami et al. 1982; Walton 1996) and in certain cases susceptible cells can be protected from the effects of HSTs with inhibitors to protein and RNA synthesis (Walton and Panaccione 1993), suggesting that active transcription and translation by the plant cell are required for toxicity. HSTs can therefore be considered molecular determinants of pathogenesis (Kohmoto and Otani 1991) and the

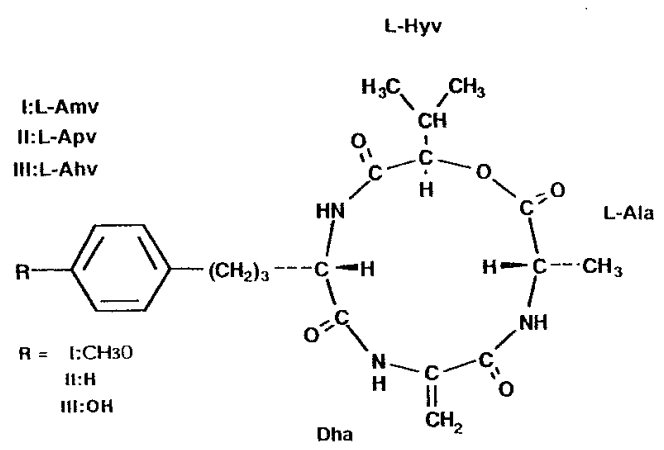

Fig. 1. Structure of AM-toxin. Abbreviations: L-Amv, L- $\alpha$-aminomethoxyphenyl-valeric acid; L-Apv, L- $\alpha$-amino-phenyl-valeric acid; LAhv, L- $\alpha$-amino-hydroxyphenyl-valeric acid; L-Hyv, L- $\alpha$-hydroxyisovaleric acid; Dha, dehydroalanine; L-Ala, L-alanine. 
study of their biosynthesis can contribute to an understanding of the molecular basis of pathogenicity as well as provide clues to how new pathogenic races of fungi evolve.

The structure of AM-toxin is not unique among HSTs as at least two other cyclic peptides show host specificity: HCtoxin produced by Cochliobolus carbonum race 1, the causal agent of leaf spot disease of maize (Walton et al. 1982; Pope et al. 1985), and victorin produced by $C$. victoriae, which causes Victoria blight on oat (Wolpert et al. 1985). Other cyclic peptides produced by fungi and bacteria also have biological significance, especially as antibiotics (Kleinkauf and von Dohren 1987; Turgay et al. 1992). These peptides are commonly synthesized via nonribosomal pathways by large multifunctional enzymes called cyclic peptide synthetases (CPSs) (Kleinkauf and von Dohren 1987; for a review see Kleinkauf and Von Dohren 1990; Marahiel 1992; Stachelhaus and Marahiel 1995a), which are highly conserved. PCR (polymerase chain reaction) with primers designed to conserved domains of CPS genes has been a good strategy to clone equivalent genes from other fungi (Turgay and Marahiel 1994; Nikolskaya et al. 1995; Annis and Panaccione 1998). Since AM-toxin biosynthesis is not inhibited by protein synthesis inhibitors (S. Yabe, personal communication) a similar system in A. alternata apple pathotype is expected to be involved. This paper describes the use of this strategy to clone and characterize a CPS gene from AM-toxin producing isolates of A. alternata apple pathotype and discusses its role as the primary determinant of pathogenicity in this plant-fungus interaction.

\section{RESULTS}

\section{PCR amplification of peptide synthetase homologs.}

PCR products of the expected size $(0.3 \mathrm{~kb})$ were obtained from three isolates (M-71, 0-159, 0-210) of A. alternata apple pathotype (data not shown) with degenerate primers cps 1 and cps2. Two PCR products, 300-1 and 300-6, obtained from the A. alternata strain M-71 were used as probes to genomic digests of A. alternata pathotypes and nonpathogenic isolates. Probes 300-1 (Fig. 2) and 300-6 gave identical results and were highly specific to the apple pathotype. These products were cloned via introduced $\mathrm{XbaI}$ sites into the plasmid vector pUC18 and sequenced with M13 universal primers. The DNA sequences of 300-1 and 300-6 were not the same, but the deduced amino acid sequences showed core motifs characteristic of peptide synthetases (Turgay and Marahiel 1994; Stachelhaus and Marahiel 1995a, 1995b), indicating that clones 300-1 and 300-6 represent different modules of the same gene. The binding sites of the degenerate primers cps 1 and cps 2 are shown in Figures 3 and 4.

\section{Features of the cloned peptide synthetase gene.}

Two sets of primers designed to the cloned 300-1 (300-1F and 300-1R) and 300-6 (300-6F and 300-6R) PCR products were used to amplify specific digoxigenin (DIG)-labeled CPS probes for use in library screening. Plaque hybridization of a Lambda Zap library with these probes identified multiple overlapping clones that were purified and converted to pBKCMV phagemids for sequencing. Sequence analysis revealed a complete open reading frame (designated $A M T$ ) of $13.1 \mathrm{~kb}$ in length that contained no introns (Fig. 3; GenBank database accession number AF184074). The locations of PCR products 300-1 and 300-6 within this sequence were 2680-2936 and 5921-6248, respectively. The derived amino acid sequence has a predicted molecular mass of $479 \mathrm{kDa}$ and BLAST searches (Altschul et al. 1997) showed high homology to other peptide synthetase genes in the data base, with the highest homology to destruxin B synthetase (PesA) from Metharizium anisopliae (Bailey et al. 1996) and HC-toxin synthetase (HTS1) from Cochliobolus carbonum (Scott-Craig et al. 1992). Four catalytic domains (designated A, B, C, and D), responsible for the activation of each residue in AM-toxin, were identified in AMT. Alignment of the four AM-toxin synthetase domains to each other and also to domain B of HCtoxin synthetase from $C$. carbonum and one domain of PesA from $M$. anisopliae is shown in Figure 4. Conserved core motifs characteristic of peptide synthetase genes (Turgay and Marahiel 1994; Stachelhaus and Marahiel 1995a, 1995b;) were also identified (Fig. 4). An unusual feature of $A M T$ was that the $\mathrm{N}$-terminal portion of domain $\mathrm{D}$ does not align with the other domains and a region of about 300 amino acids appears to be missing. Southern analysis of this region on genomic DNA from two apple pathotype isolates confirms that it is not a deleted copy or cloning artifact. With a probe (D-del) located within the cloned Domain D sequence to HindIII and EcoRI genomic digests, bands of 2.5 and $3.4 \mathrm{~kb}$ were detected (Fig. 5B). These were predicted from the restriction map of $A M T$ and no additional bands were detected,

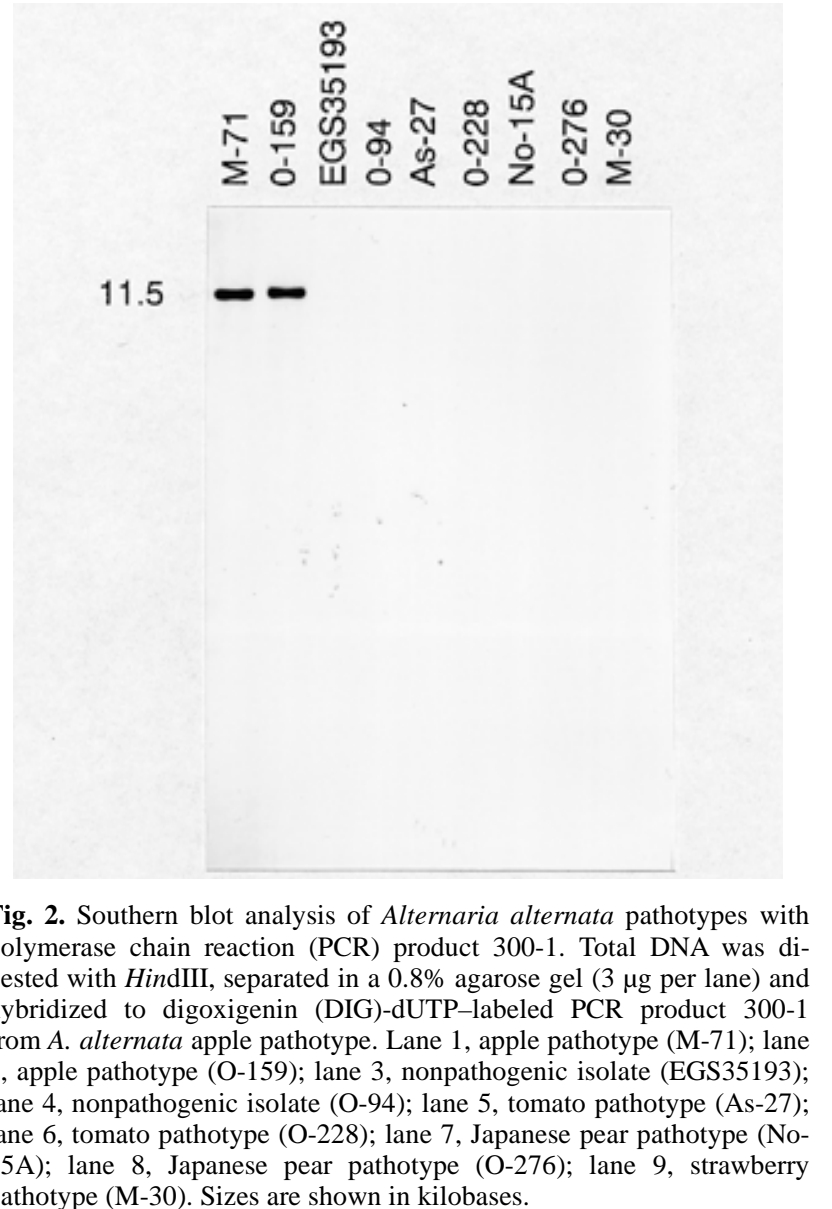


indicating that if additional copies exist their organization is the same as that of the cloned copy. In addition, reverse transcription (RT)-PCR with primers that flank this region shows that $A M T$ is expressed (Fig. 5C) and the size of the amplified product is congruent with the sequence data. This event was detected in two separately isolated clones ( $\lambda$ AMT4 and $\lambda$ AMT5; Fig. $6 \mathrm{~A}$ ), providing further evidence that it is not a cloning artifact. Since the first two core motifs conserved within other peptide synthetases appear to be missing or un- conserved in domain $\mathrm{D}$, and motif 2 has been suggested to be important for substrate recognition and amino acid activation (Gocht and Marahiel 1994; Stachelhaus and Marahiel 1995a; Etchegaray et al. 1998), this result was unexpected.

\section{Gene disruption of $A M T$.}

Transformation of $A$. alternata M-71 wild-type protoplasts with disruption vector pAMtox1 (Fig. 6A) yielded hygromycin resistant transformants at a low frequency (30 per $10^{7}$

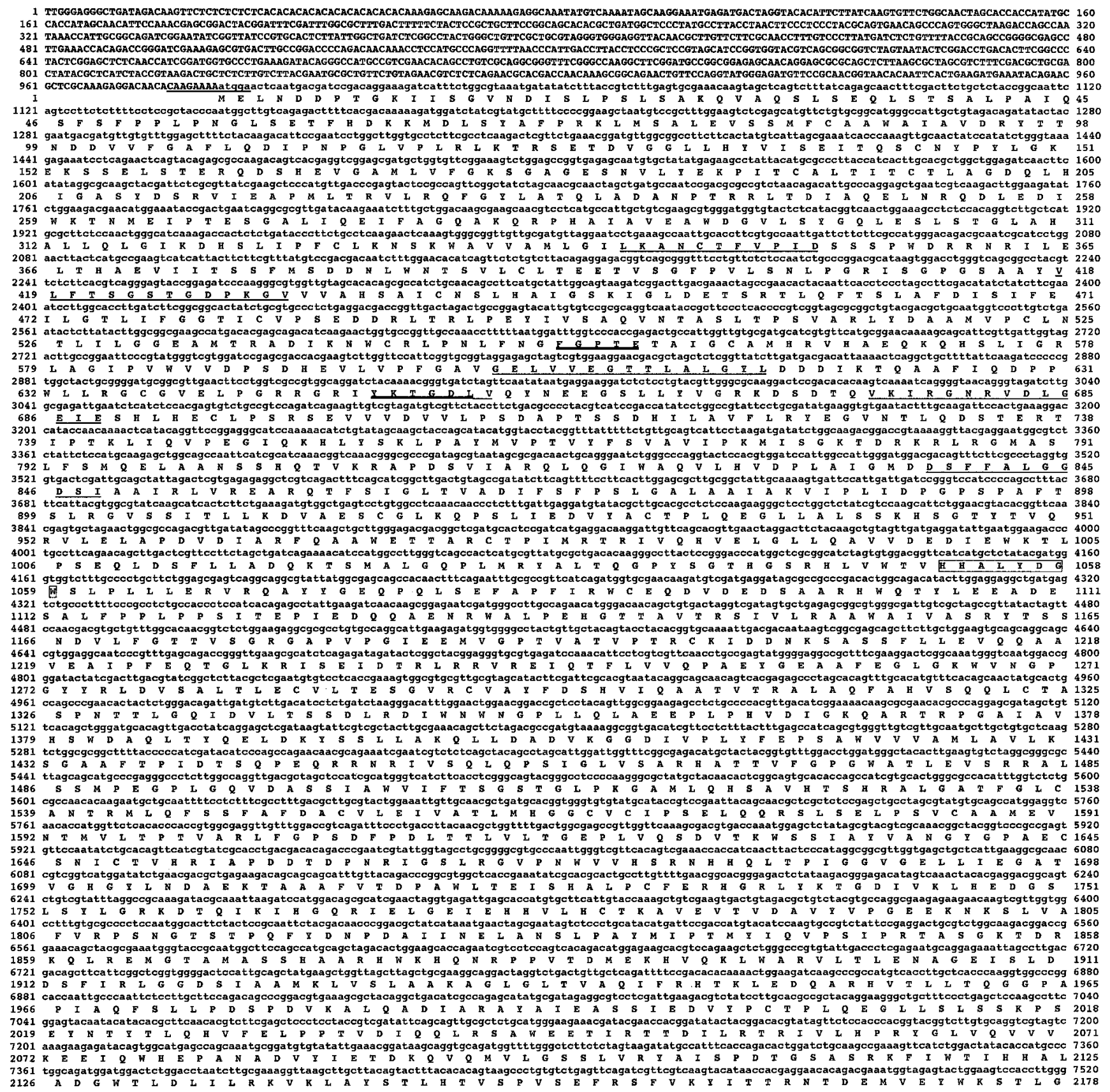

(continued on next page)

Fig. 3. Nucleotide and derived amino acid sequence of AMT. A putative Kozak consensus sequence (Kozak 1991; Bruchez et al. 1993) is indicated at position 980-990. Conserved motifs are underlined for domain A only. Degenerate polymerase chain reaction (PCR) primer binding sites are underlined in bold for domain A only. Conserved spacer motif between domains A and B is shown by a block. A putative polyadenylation site is indicated at position 14335-14340. Nucleotide and/or amino acid sequence data for AMT have been submitted to the DDBJ, GenBank, and EMBL data bases under accession number AF184074. 
protoplasts per $5 \mu \mathrm{g}$ of DNA). Transformants were singlespore purified and used for bioassays and pathogenicity tests on susceptible apple cultivars to test for AM-toxin production. In addition, DNA was isolated and screened by PCR with primers designed to detect homologous crossover events with the cloned XbaI/HindIII fragment (primer pairs $\mathrm{p} 1+\mathrm{p} 2$ and p3+p4; Fig. 6B), leading to a $2.4-\mathrm{kb}$ or $2.8-\mathrm{kb}$ band, respectively. Transformant $\mathrm{T} 2$ shows no amplification with primer pair $\mathrm{p} 1+\mathrm{p} 2$, probably due to a small deletion spanning the left hand junction of integrating plasmid and genomic DNA. Out of 30 transformants tested, approximately $70 \%$ showed a homologous disruption of $A M T$. However, PCR with primer pair $\mathrm{p} 1+\mathrm{p} 4$ (Fig. 6B) amplified a product indicative of a nondisrupted gene. This could be explained if an additional copy or copies of $A M T$ are present in the genome and was confirmed by Southern analysis (Fig. 6C). With the 300-6 product as a probe to BamHI-digested DNA, a homologous crossover into the $\mathrm{Xba \textrm {I } / H i n d I I I}$ fragment would yield bands of 4.1 and 10.0 $\mathrm{kb}$ for a single-copy integration. A multiple copy (tandem repeat) integration would also produce a strong $9.0-\mathrm{kb}$ band, as seen for transformant T1 (Fig. 6C). In all cases, the 5.1-kb, wild-type fragment was still present, indicating an additional copy of $A M T$ is present in the genome of A. alternata M-71.

\section{Copy number determination.}

Analysis of transformants showing gene disruptions indicated that an additional copy or copies of $A M T$ are present in A. alternata apple pathotype. Extensive Southern blotting with probes designed to the $3^{\prime}$ and $5^{\prime}$ ends of $A M T$ with numerous restriction enzyme digests has so far failed to iden-

Fig. 3. (continued from preceding page)

7521 cggttaccattccaccactttccetgtctgcatcgtcagtacggttgctatagaagattcagaagtagggcaaaacacgaectgccacgaaacattaccctcagcgcccacecectgtetaetttgettegcgeggettgggetattgtceagagcaac 7680 7681 tatagtaacacgagcgatgtegtttteggagaagtettttecggtcgaagtgcttcagttecgtttatcgaagecattgttgggcceaccatggetaccetaccagttcgcgtcaagattgatgattccgagctegcacgegaatgcttgaccgecttc 7840

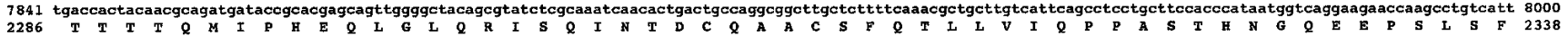
8001 ttcaggatctcoggactategectggecacetaegctctagggatcgagtgtacgectgcatctgatggatattcatt tagetgtegtgeccgtttegactcacgcgttctgtctgctcaagtagcggaacgcatgatggeacagcttgggeatgtagta 8160 8161 tegcaattggtggctgttacggcetctecttcttegagtacactcgtctcggata ttgttctgaa tacgcctcaagacctcgagaagctgtgggegtggaatgaagcggtactggaactaggagaagagcaaaagcacagcatgttgctccatcaggtct 8320

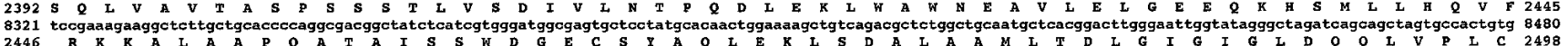
8481 ctttgagagatctatgtgggttgtcgtggccatgatggctgttttaaaactggagetggcattgtgcegttggatcetgcacacceccctagtcggcatgagaggatactcgccaaagtaggcattggegggtgcatactcgtgtcgetgcaatatgct 8640

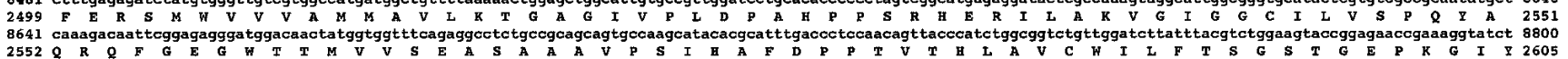
8801 atttggaacacggagccatctgtgctagctacaagctcotaggaaaacgctggggattgataaggagactcgtatgcttcact tetcagcetatgcttttgacatcgecacettcgagataataggeactttgatgtcaggtggttgeatetgcatace 8960

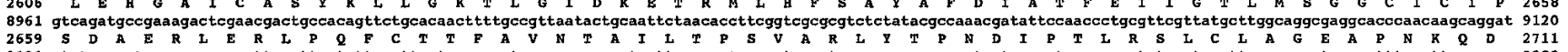

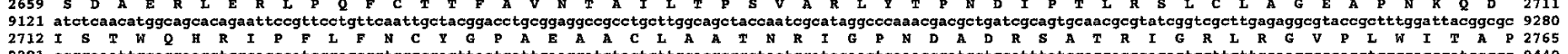

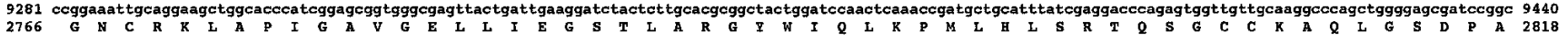
9441 agacgtggtagactctaccggaccggagatctacaagtatgacgaagacggtggagtcgtatatgaagggagaaaggacaaccaggtaaaaa tccgaggccagcgcaccgagcttggtgagatcgagtaccatctaagtcaatgctttectacagccgce 9600

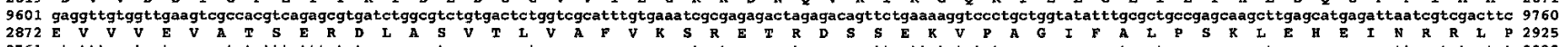

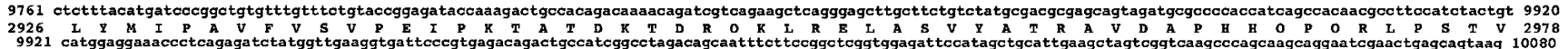

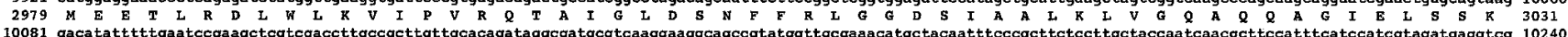
10081 gaca tatttttgaatcegaagctegtegacettgecgettgttgcacagataggcgatgcgtcaaggaaggcagecgtatggttgcgaaacatgctacaatttcccgcttctccttgctaccaatcaacgcttccatttcatccatcgtagatgaggtcg 10240

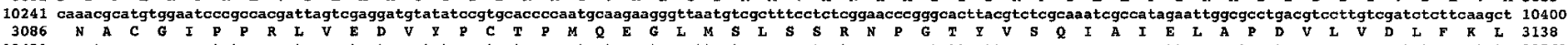

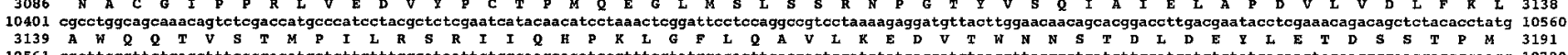
10561 ggct tcggttctgagct ttcccgacatgctct tgtt tgggataattctggcaagcacatccgtttcgtatggacagttcaccactcgatctatgaccatgtaacgttacggctgatcttggatgatgtctatgacaactacaaggggaacgagegcaagg 10720

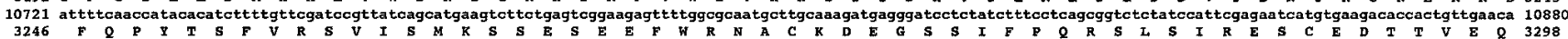

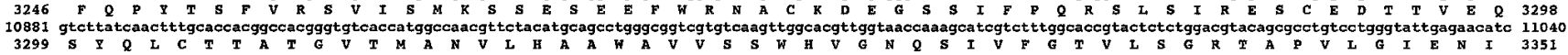

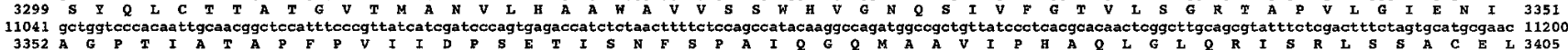
11201 ttgcetgcaattttcaaactctttttgccgtacaagaggggcgggegatggtgggcaattccttgggcaagctgctagacgtaaacacettctcaatgaggacgtacgcgttaacgctggactgtttettggatacagaaggattecacgtcaaagecag 11360

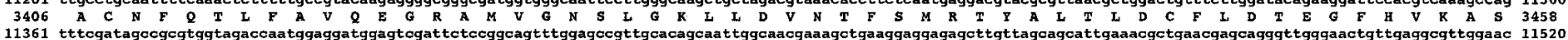

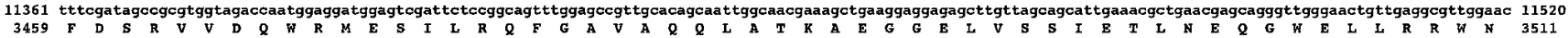

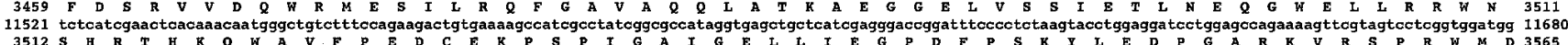

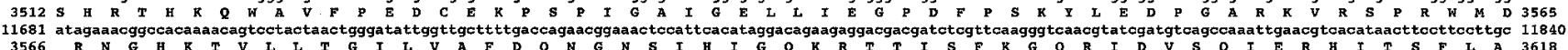
11866 ggan

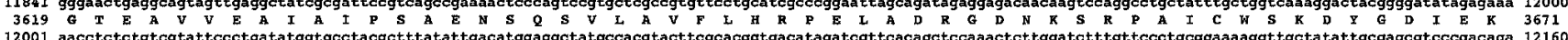

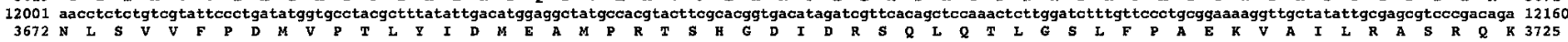

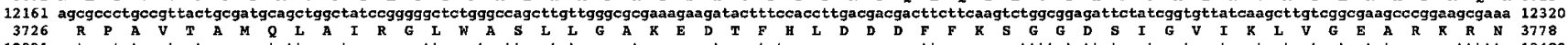
12321 catagctctagctgetgccgacatattccagtaccccaagttggagtcettagctgtgcgagetaccgagaataccetctcccaagcagaagagct tgaggagcegttttctcttatcactagctacgtggatgatgctgatcgtatcgaagacttttttg 12480 12481 agcagcaatatactctcecgaattcectatgcacgegaagcgttgcaggatgttcttccatgtacatcgatgcagaagcaactctttcacgctcaaggacagatctatcgtttcgttctagatttcggcgatgeccaaatcgatgeccatcggcttgaac 12640

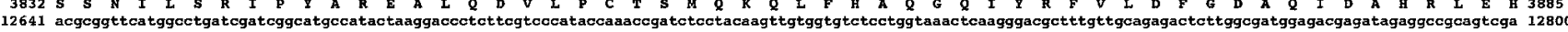

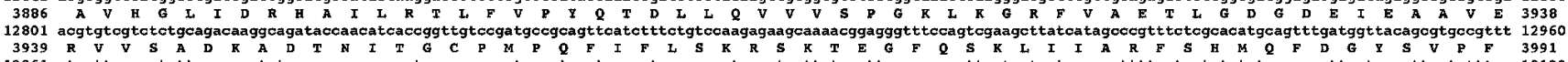

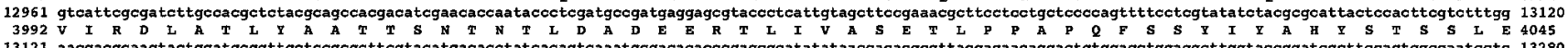

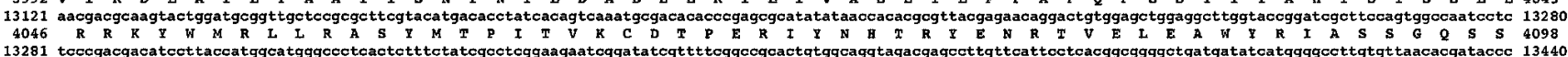
13281 tcccgacgacatcct taccatggcatgggcectcactctttctatcgcotcggaagaateggatatcgttteggecgcactgtggcaggtagacgagcettgttcattcetcacggcggggetgatgatatcatggggecttgtgttaacacgatacc 13440 13441 gtgcgagtgcagttgccgtctacaacagaacaagaagaagtagacaaaagcatgacgttacgggatctattagecgagattcataagcagaccaaggaaacattgccgttcgagagtactgggcttgacgagattgtagagcactatgccccatcaa tat 13600

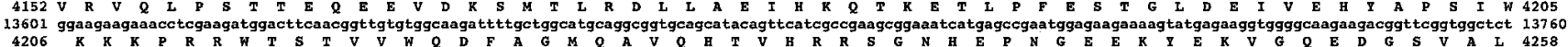
13761 aggttacatggacccgttegctgcctcttcaaatgttgcatttgcggacctgacctgcagggtgacgtgegagatacegetttttgacccggcagacgtggcggtgattggacgactggtagatgggtcaccatgetttgctettggattcgegccagag 13920

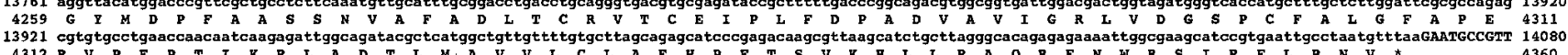

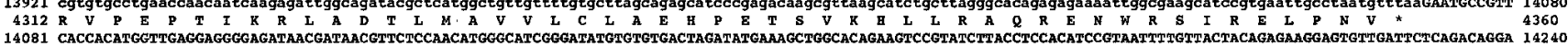
14081 CACCACATGGTTGAGGAGGGGAGATAACGATAACGTTCTCCAACATGGGCATCGGGATATGTGTGTGACTAGATATGAAAGCTGGCACAGAAGTCCGTATCTTACCTCCACATCCGTAATTITTETTACTACAGAGAAGGAGTGTTGATTCTCAGACAGGA 142 40

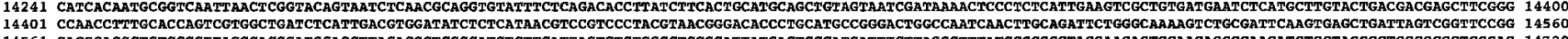
14561 CACGCAGGGTGTCCGTTACGCAGGGATGGACGTTACAGGCTCCGCATCTCTICATTACTCTCTCCGCTGCGGATTATCACTGGGATGATTTGTTACGCTTTATGCCGCGGTACGAAGAGTGGAAGACCGCAACATCTGCTAGGCGTGCCCGCCTCGCAC 14720 14881 CTATTGCAGTGGTGTTCCAGATC 
tify any polymorphisms (data not shown) but has shown the region of homology extends at least $10 \mathrm{~kb}$ on either side of the cloned sequence (Fig. 6A), indicating that $A M T$ is part of a large duplication.

\section{Bioassay and pathogenicity.}

Fifteen transformants in which a gene knockout had been confirmed by PCR and Southern analysis were tested by a leaf necrosis bioassay for their ability to produce AM-toxin. Most still produced toxin at wild-type levels, but two (T1 and T2;
Fig. 7A) produced undetectable amounts of AM-toxin when analyzed by bioassay, with the highly susceptible cultivar Indo, which can detect AM-toxin down to at least $1 \times 10^{-8} \mathrm{M}$. An ectopic transformant (T3; Fig. 7A) showed wild-type levels of necrosis.

The pathogenicity of transformant $\mathrm{T} 1$ was tested by inoculating spores onto leaves of the cultivar Indo. The wild-type isolate showed typical, brown, water-soaked lesions after $48 \mathrm{~h}$ incubation whereas the transformant showed no symptoms (Fig. 7B).
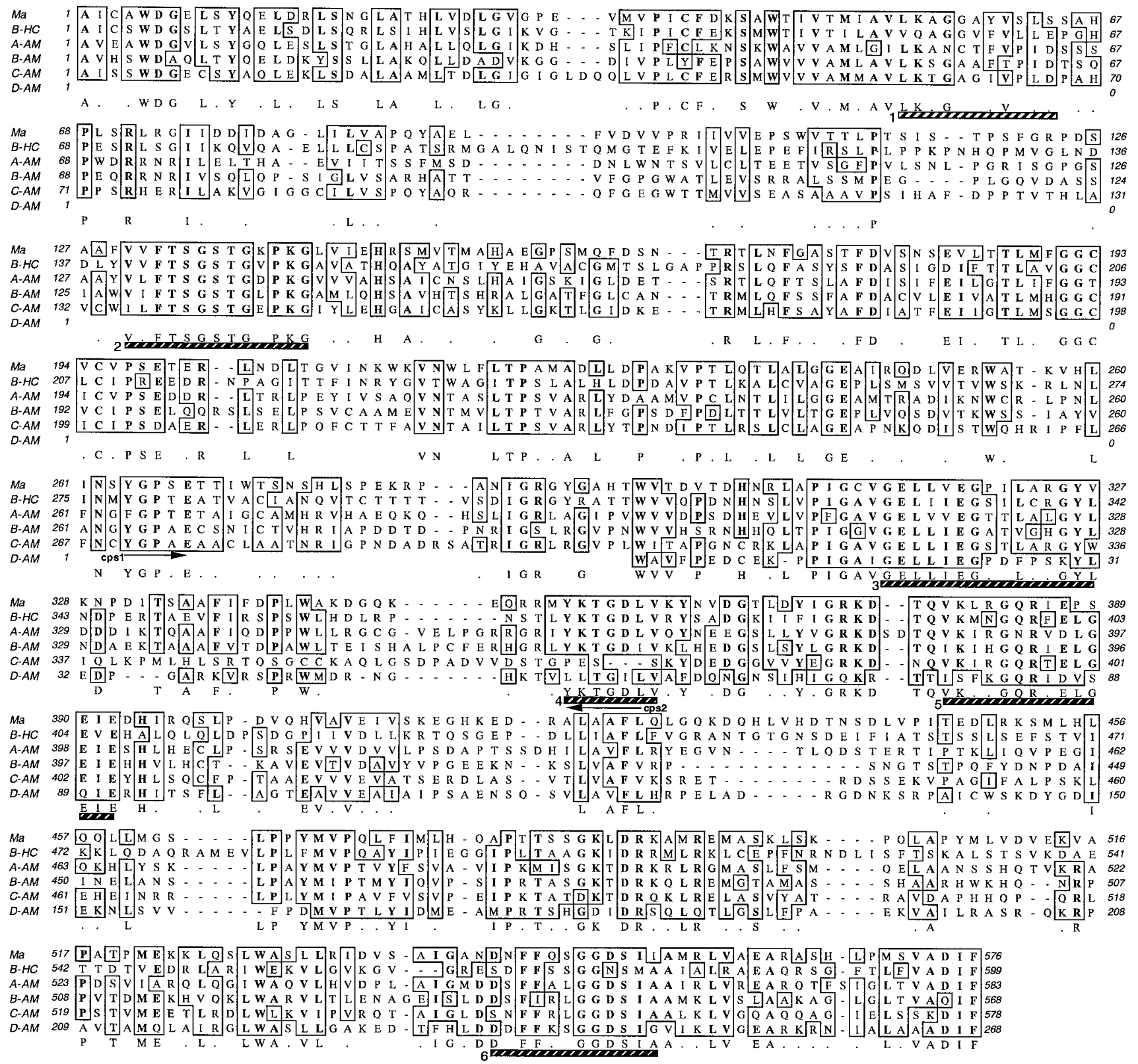

Fig. 4. Alignment of the four AM-toxin synthetase domains (A-AM, B-AM, C-AM, and D-AM) with each other and to domain B of HC-toxin synthetase from Cochliobolus carbonum (B-HC) and to a domain of PesA from Metharizium anisopliae (Ma). Conserved residues are in bold. Similarities are boxed. Core motifs 1-6 (Stachelhaus and Marahiel 1995a) are indicated by hatched lines and degenerate primer binding sites (cps1 and cps2) are shown by arrows. Multiple alignments were performed with the Clustal W algorithm (Thompson et al. 1994) with a Blosum matrix and an open gap penalty of 10 (MacVector 6.51). Aligned domains correspond to the following nucleotide positions: domain A, 1861-3600; domain B, 5122-6819; domain C, 835610089; domain D, 11542-12348. Nucleotide and/or amino acid sequence data for AMT have been submitted to the DDBJ, GenBank, and EMBL data bases under the accession number AF184074. 


\section{HPLC and RT-PCR expression analysis,}

HPLC (high-pressure liquid chromatography) analysis detected AM-toxin for both the standard and wild type at a retention time of 6.2 min under the conditions employed (Fig. $8 \mathrm{~A})$. In contrast, transformants $\mathrm{T} 1$ and $\mathrm{T} 2$ showed no equivalent peak (Fig. 8A), which is in agreement with the bioassay and pathogenicity data. An ectopic transformant (T3) shows wild type levels of toxin production.

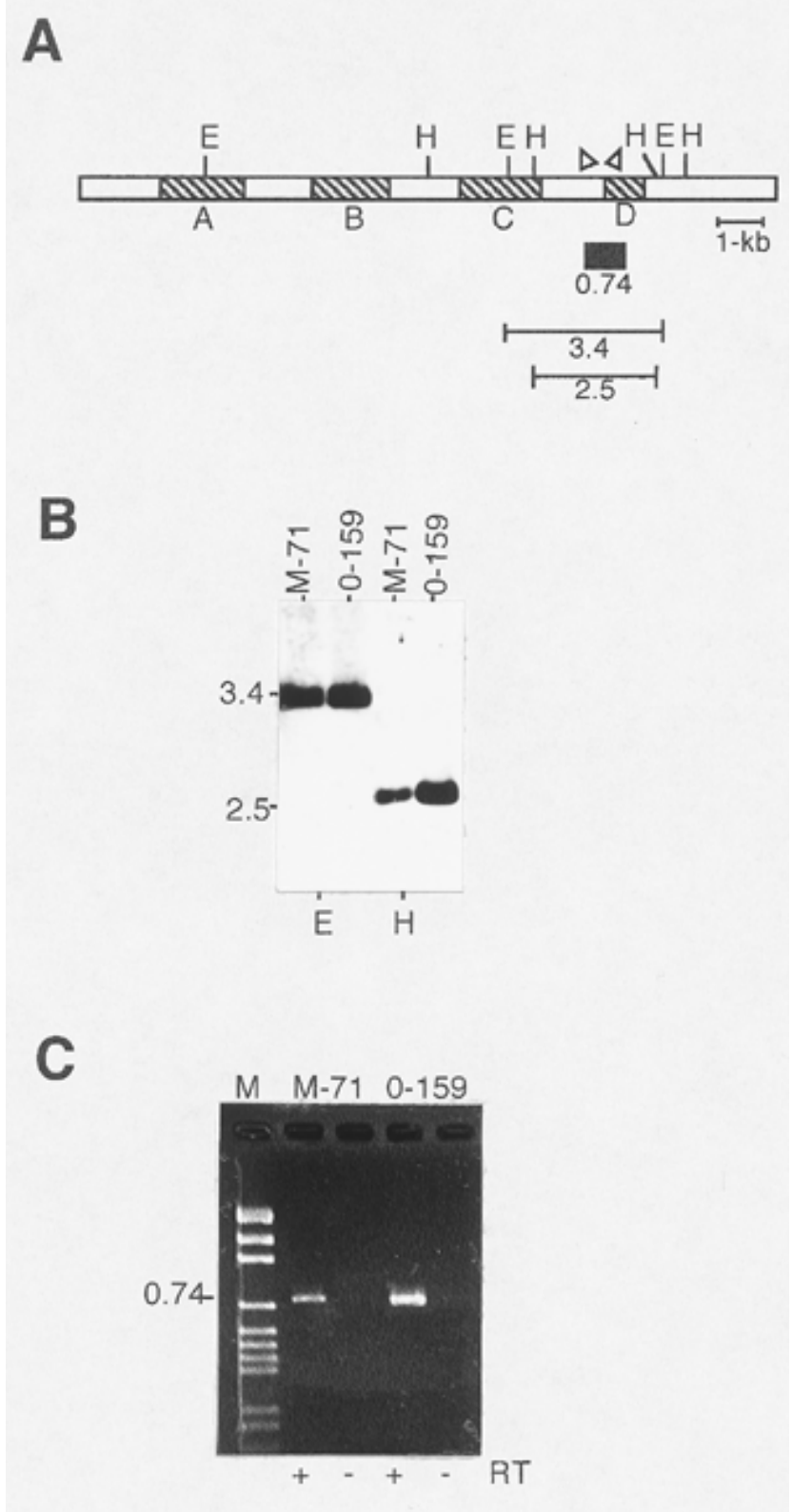

Fig. 5. Analysis of domain D by Southern blot and reverse transcription-polymerase chain reaction (RT-PCR). A, A restriction map showing locations of each domain (hatched box). Primers $d 1+d 2$ (shown by open triangles) used for RT-PCR and generation of a probe, D-del (shown by black box), are indicated. B, Hybridization of EcoRI and HindIII genomic digests of two apple pathotype isolates to a digoxigenin (DIG)labeled probe (D-del) located within domain D. E, EcoRI; H, HindIII. C, RT-PCR with primers $d 1+d 2$, which flank the proposed missing portion of domain D. + and - refer to addition or absence of reverse transcriptase in the RT-PCR. Sizes are shown in kilobases.
RT-PCR was performed on total RNA of wild type and transformants showing loss of AM-toxin production. With $A M T$ specific primers ( $\mathrm{L} 1+\mathrm{L} 2)$ the wild-type isolate and the ectopic transformant, T3, gave high levels of expression (Fig 8B). Transformants T1 and T2 showed highly reduced levels of $A M T$ expression relative to the wild type but, compared with the control containing no reverse transcriptase, were not zero. This suggests that the additional copy or copies of $A M T$ detected by Southern analysis are only weakly expressed.

\section{DISCUSSION}

We have cloned a gene (AMT) from A. alternata apple pathotype that encodes a multifunctional CPS, with a predicted molecular mass of $479 \mathrm{kDa}$, and have shown that it plays an important role in the production of AM-toxin (Fig. 1 ), an HST required for pathogenicity of this fungus on susceptible apple cultivars (Kohmoto et al. 1974). AMT is highly specific to the apple pathotype, with other related A. alternata pathotypes or nonpathogenic isolates having no detectable homology (Fig. 2). This is similar to four other genes cloned so far that determine fungal host specificity: HTS1 of C. carbonum race 1 (Ahn and Walton 1996); pksl of Cochliobolus heterostrophus race T (Yang et al. 1996); avr9 of Cladosporium fulvum (van Kan et al. 1991); and AKT1 plus AKT2 from A. alternata Japanese pear pathotype (Tanaka et al. 1999). These genes are found only in the producer of the specific toxin or elicitor with no allele present in the nonproducing strains. There is therefore accumulating evidence that many host-specificity determining genes are not allelic, raising questions as to where and how these genes were obtained by these organisms. It has been proposed that horizontal gene transfer may be responsible for the acquisition of genes for HST biosynthesis in C. carbonum and C. heterostrophus (Nikolskaya et al. 1995; Ahn and Walton 1996; Yang et al. 1996; Yoder 1998) and, given that A. alternata pathotypes appear to differ only in relation to the genes required for HST biosynthesis (Kuninaga and Yokosawa 1987; Kusaba and Tsuge 1994, 1995), this may be a possible mechanism whereby A. alternata pathotypes evolved.

The evidence that $A M T$ is involved in AM-toxin production is threefold. First, AM-toxin is a cyclic peptide and experimental evidence from this laboratory shows that it is synthesized nonribosomally (S. Yabe, personal communication). Nonribosomal synthesis typically involves large, multifunctional enzymes called peptide synthetases (for a review see Kleinkauf and von Dohren 1990; Marahiel 1992). AMT shows high similarity to other peptide synthetase genes and is highly specific to and only expressed in AM-toxin producing strains. Second, the adenylate-activating domains in CPSs are responsible for the activation and thioesterification of each constituent amino acid during peptide synthesis (Smith et al. 1990). We identified four domains within $A M T$, which equals the number of constituent residues in AM-toxin. Third, gene disruption into an active copy of $A M T$ reduces AM-toxin production to undetectable levels.

$A M T$ does not contain any introns based on the absence of stop codons, frame shifts, and fungal intron consensus sequences (Ballance 1991). The proposed ATG start codon (Fig. 3) was chosen since no in-frame upstream ATG was present 
and the surrounding bases fit well with the consensus Kozak sequence, CNNNCA(AC)NATGGC, identified for filamentous fungi (Kozak 1991; Bruchez et al. 1993). In addition, a putative polyadenylation site was identified after the proposed stop codon (Fig. 3). The absence of introns in $A M T$ is not unusual since, with the exceptions of pesA from Metharizium anisopliae (Bailey et al. 1996) and Psl from Claviceps purpurea (Tudzynski et al. 1999), several other fungal peptide synthetase genes also lack introns (Diez et al. 1990; Smith et al. 1990; Gutiérrez et al. 1991; Scott-Craig et al. 1992; Haese et al. 1993; Weber et al. 1994).
The copy number of $A M T$ appears to be at least two, based on Southern analysis and PCR of gene disruption transformants. In addition, the majority of these transformants still produced toxin, providing further evidence of a multicopy nature for $A M T$. Southern analysis of wild-type DNA has indicated that the duplicated region extends at least $10 \mathrm{~kb}$ either side of the cloned sequence presented here, making actual copy number determination difficult, but physical mapping with pulsed-field gel electrophoresis has shown that all copies of $A M T$ reside on the same small chromosome (Akamatsu et al. 1999; R. D. Johnson, unpublished). Restriction digests

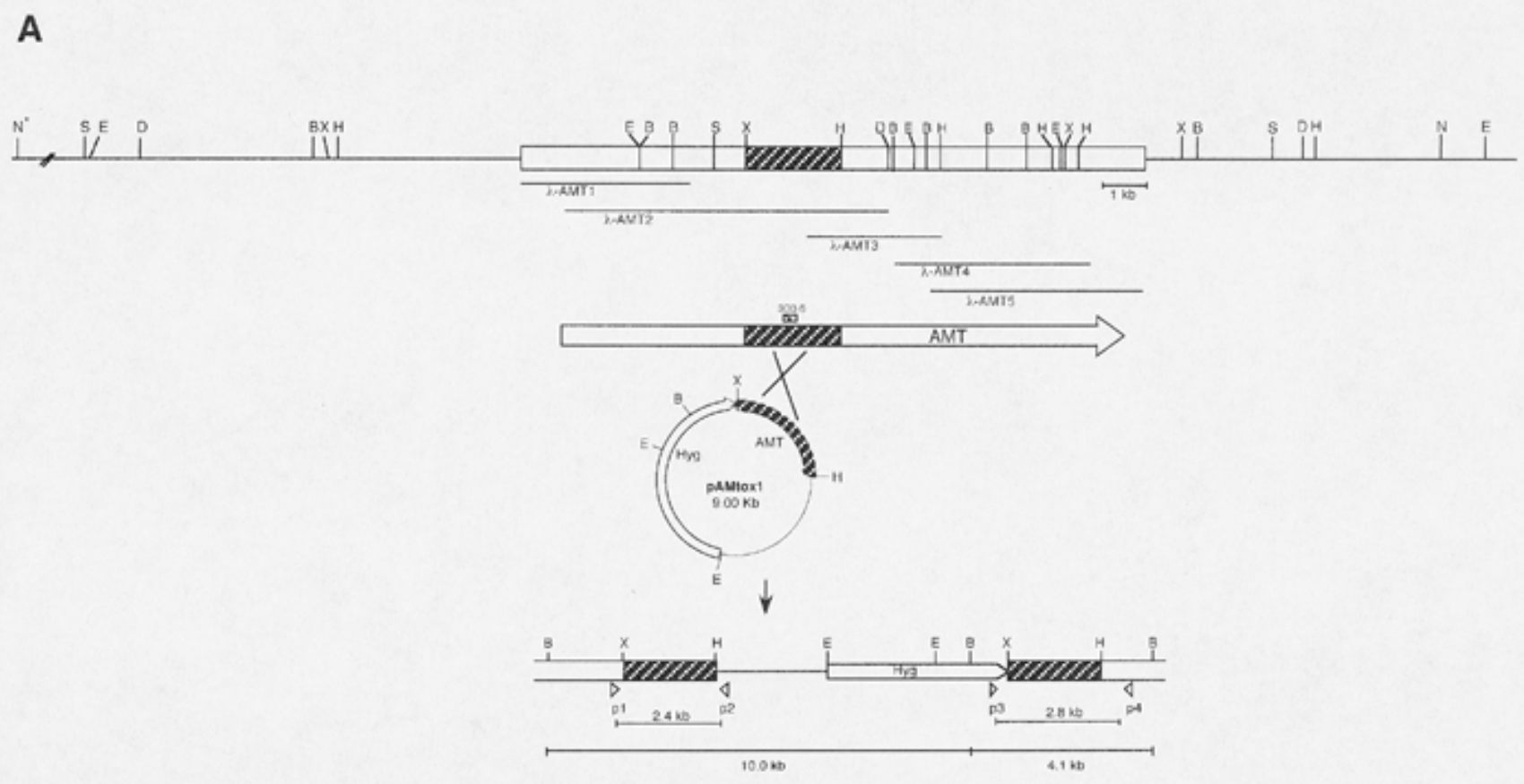

B
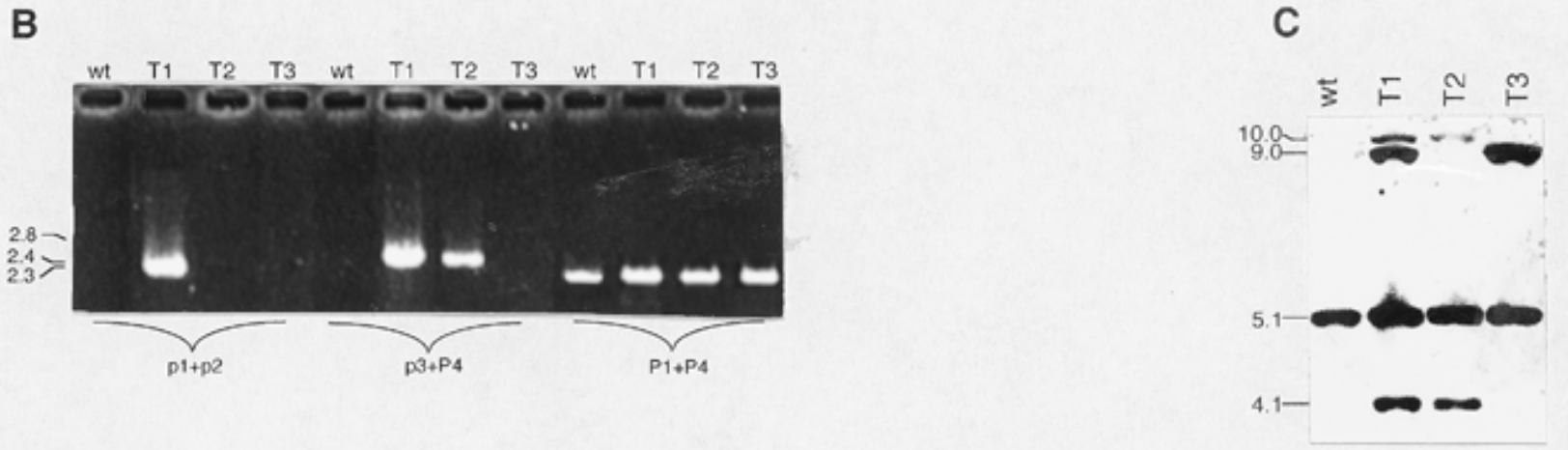

Fig. 6. Restriction map and gene disruption strategy for AM-toxin synthetase. A, Restriction map and location of lambda clones isolated during library screening. B, BamHI; D, DraI; E, EcoRI; H, HindIII; N, NotI; S, SpeI, X, XbaI. Sites located outside of boxed region (Sequenced) assigned by Southern analysis only. The $5^{\prime}$ NotI site (asterisk) is not accurately assigned and is between 35 and $50 \mathrm{~kb}$ from the $3^{\prime}$ NotI site. Location of the AMT open reading frame is indicated by an open arrow. A 2.2-kb XbaI/HindIII fragment (shown by hatched box) was subcloned from $\lambda$-AMT2 into pAN7-1 (Punt et al. 1987) to make pAMtox1. Outcome of a homologous crossover between cloned and genomic DNA is shown. Location of probe (300-6) used to detect homologous recombination is indicated. Primers used to detect junctions between plasmid and genomic sequences in homologous crossovers are shown by open triangles. Hyg is a hygromycin resistance cassette. B, Polymerase chain reaction analysis of wild type and transformants with primers designed to detect homologous recombination events. Wt, wild type strain M-71; T1 and T2, toxin minus transformants; T3, transformant showing ectopic integration. Primers $\mathrm{p} 1+\mathrm{p} 2$ and $\mathrm{p} 3+\mathrm{p} 4$ detect left and right junctions between plasmid and genomic sequences respectively. Primers $\mathrm{p} 1+\mathrm{p} 4$ detect wild type (amplification) or disrupted (no amplification) fragment. Size markers are in kilobases. C, Southern blot analysis of wild type and transformants with probe 300-6 to detect homologous recombination. Size markers are in kilobases. 
with rare base cutters and pulsed-field gel electrophoresis may well resolve the different copies of the gene. Since it was possible to obtain AM-toxin minus transformants through gene disruption we conclude that only one copy of $A M T$ is expressed or the additional copies make nonfunctional proteins. RT-PCR analysis on these mutants suggests that the additional copy or copies have extremely low but not zero levels of expression so whether they encode functional proteins is uncertain. This is not dissimilar to the case of $A K T 1$ and $A K T 2$ from A. alternata Japanese pear pathotype, which are required for AK-toxin biosynthesis, where nonfunctional homologues of these genes are also present (Tanaka et al. 1999).

The domain organization of peptide synthetase genes is now well understood. Numerous core motifs have been identified within the catalytic domains of all peptide synthetases and putative roles have been assigned (for a review see Marahiel 1992; Stachelhaus and Marahiel 1995a). Of the four domains in $A M T$, domain $\mathrm{D}$ appears to partially differ from the other three and also from those of other peptide synthetases. Core motifs 1 and 2 are either not conserved or are not present. Southern hybridization showed that this was not just a cloning artifact and RT-PCR of this region indicates that the gene is expressed and therefore not a nonfunctional copy (Fig. 5). The absence of recognizable core motifs 1 and 2 is interesting, particularly since core motif 2 (VxFTSGSTGxPKG) has been suggested to be important in substrate recognition and adenylate activation (Stachelhaus and Marahiel 1995a, 1995b; Etchegaray et al. 1998; Stachelhaus et al. 1999). To date, there is no easy way to infer which domain recognizes and activates a particular amino acid by sequence comparison alone, so a definitive role for domain $\mathrm{D}$ cannot be assigned. It is possible that domain $\mathrm{D}$ is nonfunctional in this capacity and that this role is carried out by another peptide synthetase, as some fungi appear to have multiple families of peptide synthetase genes (Pannaccione 1996). In addition, it is highly likely that $A M T$ is part of a gene cluster, as has been recently shown for the HC-toxin biosynthetic pathway (Ahn and Walton 1996, 1997, 1998) and fungal secondary metabolite pathways in general (Keller and Hohn 1997). Cloning of the genes that flank $A M T$ is now underway, with an aim to identify other components of the AM-toxin biosynthetic pathway.

In conclusion, we have cloned and characterized a gene (AMT) that is highly specific to A. alternata apple pathotype, and shown through gene disruption that it is a crucial component of the AM-toxin biosynthetic pathway. This, together with AM-toxin having high specificity to a narrow range of susceptible apple cultivars, clearly shows that $A M T$ is a major pathogenicity determinant of this fungal-plant interaction.

\section{MATERIALS AND METHODS}

\section{Plant material, fungal strains, and culture conditions.}

Apple (Malus domestica Borkh.) leaves were obtained from greenhouse-grown apple trees of the highly susceptible cultivar Indo. Isolates of A. alternata apple pathotype (strains M71, O-159, and O-210), Japanese pear pathotype (strains O276 and No-15A), tomato pathotype (strains O-228 and As27), strawberry pathotype (strain M-30), and two A. alternata nonpathogenic isolates (strains EGS35193 and O-94) were used in this study and have been described previously
(Akamatsu et al. 1999). All isolates were maintained on potato dextrose agar (Difco, Detroit, MI) slopes or as $15 \%$ glycerol spore suspensions at $-80^{\circ} \mathrm{C}$.

\section{DNA manipulations.}

Genomic DNA was extracted as described previously (Akamatsu et al. 1997) and nucleic acid manipulations followed standard procedures (Sambrook et al. 1989). Restriction digestions were carried out with $5 \mu \mathrm{g}$ of DNA according to the manufacturer's instructions (Toyobo, Tokyo) and fractionated in $0.8 \%$ agarose gels. Fractionated DNA was transferred to Hybond-N membranes (Amersham, Bucks, UK) by capillary transfer under alkaline conditions (Reed and Mann 1985). DIG-labeled probes were generated by PCR with the DIG-DNA labeling and detection kit (Boehringer Mannheim, Tokyo). Hybridization and washing were conducted under high stringency according to the manufacturer's instructions.

\section{Amplification of CPS catalytic domain.}

A set of degenerate primers (cps1, 5'-AAT CTA GAT AYG GNC CNA CNG A-3', and cps2, 5'-CCT CTA GAN AGR TCN CCN GTY TTR-3'), whose target sequence is illustrated in Figures 3 and 4, was designed to conserved catalytic domains of peptide synthetase enzymes (Nikolskaya et al. 1995; Annis and Panaccione 1998). To facilitate cloning, XbaI sites were incorporated at the $5^{\prime}$ ends. PCR was performed on genomic DNA of A. alternata (strains M-71, O-159, and O210) under the following conditions: $20 \mathrm{ng}$ of genomic DNA was added to a $20-\mu l$ reaction containing dNTPs at a final concentration of $250 \mu \mathrm{M}$ (Takara, Tokyo), 1× PCR buffer (Takara), primers cps 1 and cps2 at a final concentration of 1 $\mu \mathrm{M}$ (Pharmacia Biotech, Tokyo) and 1.0 U of Taq DNA polymerase (Takara). PCR was performed in a GeneAmp PCR system 9600 (Perkin-Elmer, Tokyo) with an initial step of 5 min at $95^{\circ} \mathrm{C}$ followed by 30 cycles of $15 \mathrm{~s}$ at $95^{\circ} \mathrm{C}, 15 \mathrm{~s}$ at $50^{\circ} \mathrm{C}, 30 \mathrm{~s}$ at $60^{\circ} \mathrm{C}$, and a final step of $5 \mathrm{~min}$ at $60^{\circ} \mathrm{C}$.

\section{Library screening.}

A. alternata genomic DNA (strain M-71) was partially digested with $\mathrm{MboI}$ and fragments in the range of 10 to $12 \mathrm{~kb}$ were cloned into the BamHI site of Lambda Zap (Stratagene, La Jolla, CA). Recombinant phage were plated and subsequently lifted onto nylon membranes (Hybond-N, Amersham, Bucks, UK) by standard procedures (Sambrook et al. 1989). Peptide synthetase specific probes were simultaneously amplified and labeled with a DIG-PCR labeling kit (Boehringer Mannheim) with primer pairs (300-1F, 5'-ACT GCC ATT GGT TGT GCG AT-3' and 300-1R, 5'-CAG GAA GTT CAA CGC CGC AT-3'; 300-6F, 5'-CGC CGA GTG TTC CAA TAT CTG-3' and 300-6R, 5'-CCG TCT TAT AGA GTC TCC CGT-3') that nested the PCR products originally amplified with degenerate primers cps 1 and cps2. PCR cycling conditions were as described above except that the annealing temperature was $65^{\circ} \mathrm{C}$ and the extension temperature $72^{\circ} \mathrm{C}$. Membranes were hybridized with DIG-labeled probes and washed according to the manufacturer's instructions (Boehringer Mannheim). Hybridizing plaques were detected with a colormetric reaction according to the manufacturer's instructions (Boehringer Mannheim). Positive plaques were selected and subjected to further rounds of screening until 
pure. Individual positive plaques were converted to phagemids (pBK-CMV; Stratagene) by in vivo excision according to the manufacturer's instructions, and maintained on LB (LuriaBertani) agar supplemented with $50 \mu \mathrm{g}$ of kanamycin per ml. Phagemid DNA was isolated from overnight cultures of host strain XLOR with Plasmid Mini Kits (Qiagen, Hilden, Germany) and sequenced with T3 and T7 primers (Amersham Pharmacia Biotech, Tokyo) that flank the insert. Primer walking was used to obtain the full sequence of the overlapping clones. Additional flanking clones were obtained by screening the library with DIG-labeled probes generated by PCR with primer pairs designed to the $5^{\prime}$ and $3^{\prime}$ ends of clones obtained in the initial screen.

\section{Sequencing.}

Sequencing reactions were prepared with the Thermosequenase Fluorescent Labeling Kit (Amersham Pharmacia Biotech, Tokyo) and sequenced on an ALF-express automated sequencing system (Pharmacia Biotech, Tokyo). DNA was sequenced in both directions and sequence construction was performed with Sequencer (Gene Codes, Ann Arbor, MI).

\section{Disruption vector construction.}

A 2.2-kb XbaI/HindIII fragment corresponding to $A M T$ coding sequence within domain $\mathrm{B}$ was subcloned from a phagemid (converted from $\lambda$ AMT2 by in vivo excision) into the fungal transformation vector pAN7-1 (Punt et al. 1987), which confers resistance to the selectable marker hygromycin B, to form pAMtox1 (Fig. 6A). Plasmid DNA was prepared with Plasmid Mini Kits (Qiagen) and used to transform protoplasts of A. alternata strain M-71.

\section{Transformation.}

Protoplasts were prepared from A. alternata wild type (strain M-71) as described previously (Akamatsu et al. 1999) except that $10 \mathrm{mg}$ of lysing enzyme per $\mathrm{ml}$ (Sigma) and $10 \mathrm{mg}$ of kitalase per ml (Wako Pure Chemical Industries, Osaka, Japan) replaced the enzymes originally used. Protoplasts $(1 \times$ $\left.10^{7} ; 80 \mu \mathrm{l}\right)$ were transformed with $5 \mu \mathrm{g}$ of circular pAMtox 1 by methods described previously (Akamatsu et al. 1997). Transformants were selected on plates containing $100 \mu \mathrm{g}$ of hygromycin B per $\mathrm{ml}$ and the fate of the transforming DNA determined by PCR, restriction digest, and Southern blotting according to standard procedures. Primers used to detect the junctions between plasmid and genomic sequences in homologous crossovers are shown in Figure 6 and have the following sequences: p1, 5'-GCC TCT GCC CCA CGT TGA CAT CGG AAA ACA-3'; p2, 5'-CAG CTG GCG AAA GGG GGA TGT GCT GCA AGG-3'; 3 , 5'-AGG ATC TCG ATA AGA TAC GTT CAT TTG TCC-3'; p4, 5'-TCT GAA CTC AGA CAC AGG GCT TAC TGT GTG-3'. PCR cycling conditions are as described for library screening.

\section{Bioassay and pathogenicity.}

For a leaf necrosis bioassay, cultures of wild type and transformants were grown at $26^{\circ} \mathrm{C}$ in $50 \mathrm{ml}$ of Czapek Dox medium (Oxoid, Hampshire, UK) supplemented with $0.5 \%$ yeast extract (Difco, Detroit, MI) for 6 days with no shaking. The culture filtrate was collected and $20 \mu \mathrm{l}$ placed onto the underside of a young leaf, of the highly susceptible cultivar Indo, that had been slightly wounded by scratching the epidermis. Leaves were incubated at $26^{\circ} \mathrm{C}$ overnight in the dark and assessed for necrosis after $24 \mathrm{~h}$. The remainder of the culture

\section{A}

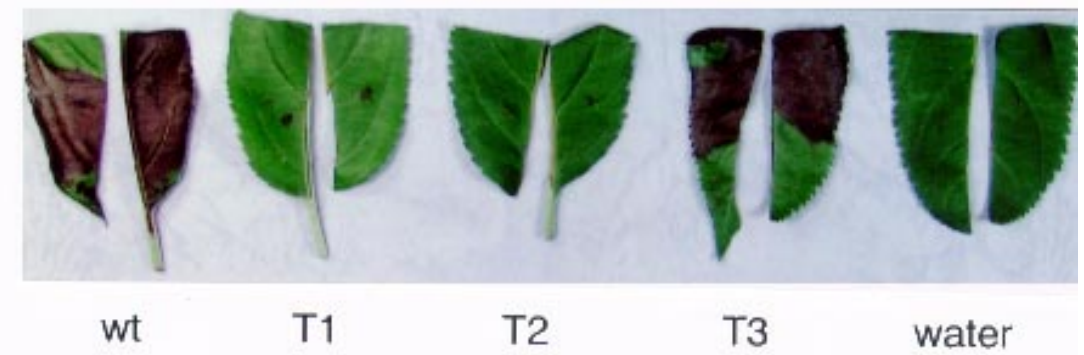

B

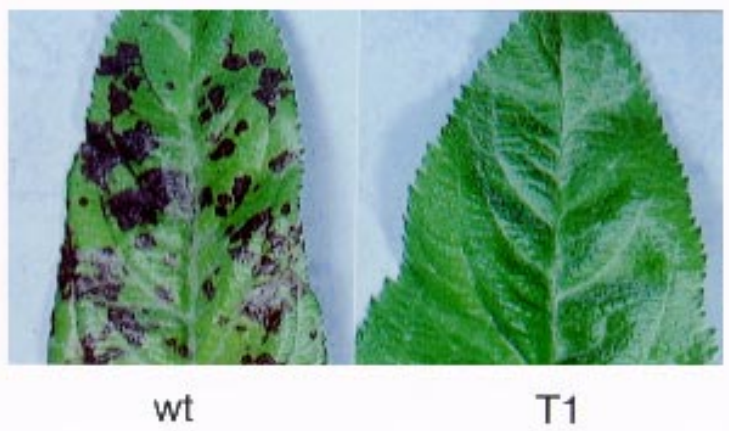

Fig. 7. Leaf necrosis bioassay and pathogenicity test. A, Leaf necrosis bioassay with culture filtrates from wild type and transformants with highly susceptible cultivar Indo. B, Pathogenicity test by spore inoculation with wild type and toxin minus transformant, T1. Wt, wild-type strain M-71; T1 and T2, toxin minus transformants; T3, transformant showing ectopic integration. 
filtrate was further purified for HPLC as described below and fungal mycelium was collected and frozen at $-80^{\circ} \mathrm{C}$ for use in RNA extraction.

For pathogenicity tests, spores of wild type and transformants were collected from mycelial mats grown in potato dextrose broth (Difco) for 2 weeks with no shaking. Spores were washed three times in sterile water and suspensions $(5 \times$ $10^{5}$ spores per $\mathrm{ml}$ ) were sprayed onto the underside of detached leaves of cultivar Indo with a glass atomizer and incu-

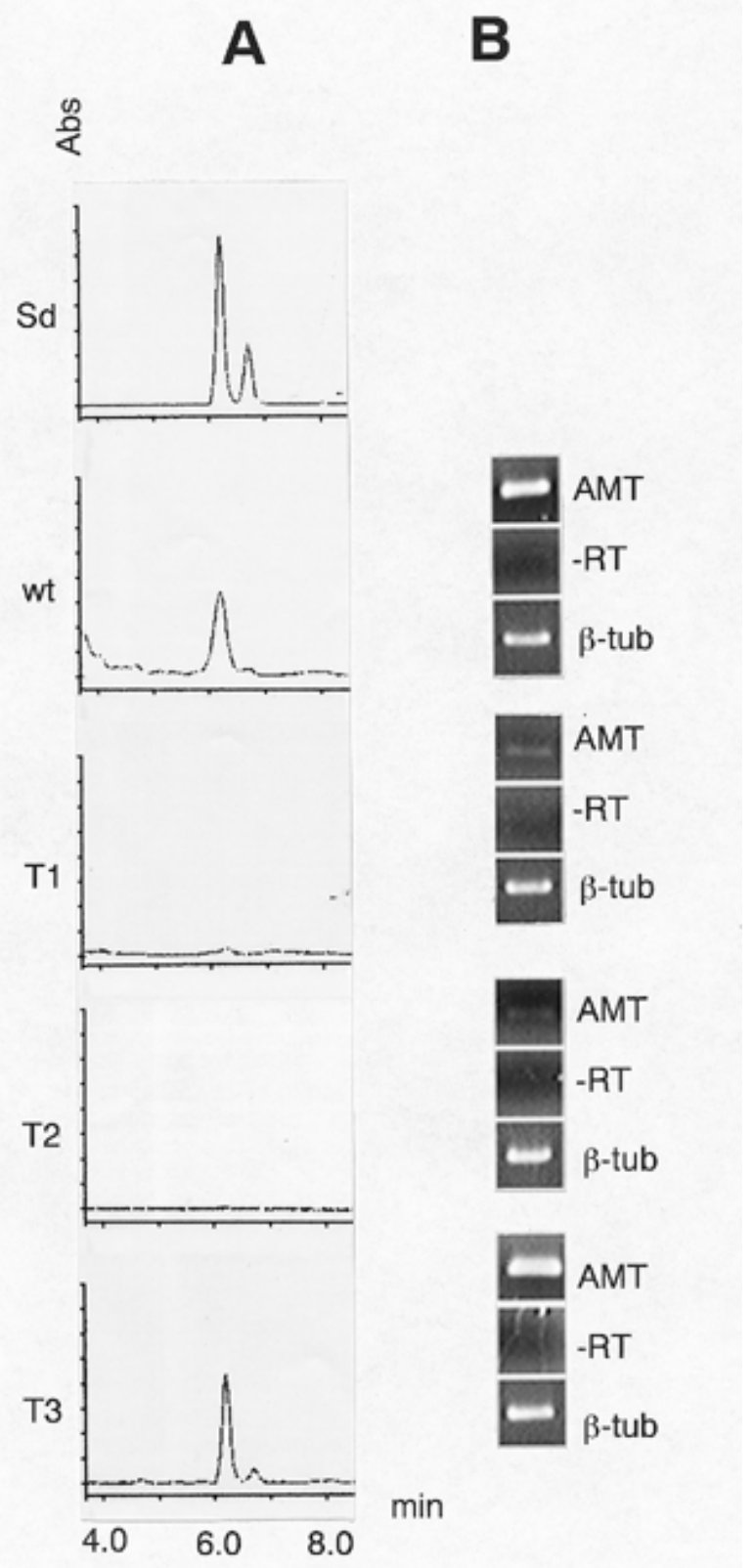

Fig. 8. High-pressure liquid chromatography (HPLC) and reverse transcription-polymerase chain reaction (RT-PCR). A, HPLC showing peaks for AM-toxin standard (Sd), wild type (wt), two toxin minus transformants (T1 and T2), and an ectopic transformant (T3). Second peak seen in the standard corresponds to AM-toxin II. Abs is absorbance at 225 $\mathrm{nm}$. B, RT-PCR on total RNA extracted from same isolates used for HPLC. AMT, $A M T$ gene specific primers (L1+L2); - RT, negative control with no reverse transcriptase in the reaction; $\beta$-tub, positive control with $\beta$-tubulin specific primers $(\beta$-tub1+ $\beta$-tub2). bated at $26^{\circ} \mathrm{C}$ for $48 \mathrm{~h}$ in the dark, after which lesion development was evaluated.

\section{HPLC.}

Culture filtrate, collected as described above, was briefly centrifuged to remove debris and $5 \mathrm{ml}$ was concentrated to 1 $\mathrm{ml}$ by evaporation. Two volumes of acetonitrile $(\mathrm{MeCN})$ were added and mixed, and the phases allowed to separate. The $\mathrm{MeCN}$ phase was taken and evaporated to dryness. The residue was washed once in $\mathrm{MeCN}$, evaporated to dryness, and finally resuspended in $250 \mu \mathrm{l}$ of $50 \% \mathrm{MeCN}$. For HPLC, $10 \mu \mathrm{l}$ was injected into a Devlosil ODS-UG-5 column (Nomura Chemical, Seto, Japan) equipped with an L-6200 pump and analyzed with a L3000 photodiode array detector and D-6000 data station (Hitachi Scientific Instrument, Tokyo). Running solvent was $50 \% \mathrm{MeCN}$ at a flow rate of $0.7 \mathrm{ml} / \mathrm{min}$.

\section{RT-PCR.}

Total RNA was prepared from frozen fungal mycelium (100 $\mathrm{mg}$ fresh weight), collected as described for bioassays above, by RNeasy Plant Mini Kits (Qiagen) according to the manufacturer's instructions, and buffer RLT. Ten micrograms of total RNA was DNaseI treated to remove traces of contaminating DNA and $1 \mu \mathrm{g}$ was reverse transcribed into cDNA by the Thermoscript RT-PCR system (Life Technologies Oriental, Tokyo) according to the manufacturer's conditions and AMT specific primers (L1, 5'-GCA CTT ACG TCT CGC AAA TCG CCA TAG AAT-3'; L2, 5'-TCT CGA ATG GAT AGA GAC CGC TGA GGA A-3' or d1, 5'-GCT GTT ATC CCT CAC GCA CAA CTC GGC TTG-3'; d2, 5'-GGA ATC GCG ATA GCC TCA ACT ACT GCC TCA-3'). $\beta$-Tubulin specific primers $(\beta$-tub1, 5'-TCC GTC GTG CCT TCC CCC AAG GTC TCC GAC-3'; $\beta$-tub2, 5'-GGA GCG AAT CCG ACC ATG AAG AAG TGG AGA-3') were used for positive controls. Duplicate reactions without the addition of reverse transcriptase acted as controls to test for DNA contamination. Two microliters of the cDNA reaction was used in a $20-\mu \mathrm{l}$ PCR with the same sets of primers and the following conditions: Reagents were as described above, and PCR cycling conditions were an initial step of $2 \mathrm{~min}$ at $94^{\circ} \mathrm{C}$ followed by 30 cycles of $30 \mathrm{~s}$ at $94^{\circ} \mathrm{C}, 30 \mathrm{~s}$ at $65^{\circ} \mathrm{C}, 45 \mathrm{~s}$ at $72^{\circ} \mathrm{C}$, and a final step of $7 \mathrm{~min}$ at $72^{\circ} \mathrm{C}$.

\section{ACKNOWLEDGMENTS}

We would like to acknowledge Jonathan Walton (Department of Energy Plant Research Laboratory, Michigan State University, East Lansing 48824, USA) for helpful discussions, Yachiyo Kawamoto and Reiko Kiyohara for technical support, and Hiroki Tabira (Laboratory of Plant Biotechnology, Tottori Horticultural Experimental Station, Kurayoshi 682, Japan) for kindly donating apple leaves for use in bioassays. This work was supported by a Japan Society for the Promotion of Science (JSPS) fellowship to R. D. J. and grants in aid for scientific research from the Ministry of Education, Science, Sports and Culture of Japan (no. 97131 to R. D. J. and no. 08044207 to K. K.).

\section{LITERATURE CITED}

Ahn, J. H., and Walton, J. D. 1996. Chromosomal organization of TOX2, a complex locus controlling host-selective toxin biosynthesis in Cochliobolus carbonum. Plant Cell 8:887-897.

Ahn, J. H., and Walton, J. D. 1997. A fatty acid synthase gene in Cochliobolus carbonum required for production of HC-toxin, cyclo(D- 
prolyl-L-alanyl-D-alanyl-L-2-amino-9,10-epoxi-8-oxodecanoyl). Mol. Plant-Microbe Interact. 10:207-214.

Ahn, J. H., and Walton, J. D. 1998. Regulation of cyclic peptide biosynthesis and pathogenicity in Cochliobolus carbonum by TOXEp, a novel protein with a bZIP basic DNA-binding motif and four ankyrin repeats. Mol. Gen. Genet. 260:462-469.

Akamatsu, H., Itoh, Y., Kodama, M., Otani, H., and Kohmoto, K. 1997. AAL-toxin-deficient mutants of Alternaria alternata tomato pathotype by restriction enzyme-mediated integration. Phytopathology 87: 967-972.

Akamatsu, H., Taga, M., Kodama, M., Johnson, R., Otani, H., and Kohmoto, K. 1999. Molecular karyotypes for Alternaria plant pathogens known to produce host-specific toxins. Curr. Genet. 35:647-656.

Altschul, S. F., Madden, T. L., Schaffer, A. A., Zhang, J., Zhang, Z., Miller, W., and Lipman, D. J. 1997. Gapped BLAST and PSI-BLAST: a new generation of protein database search programs. Nucleic Acids Res. 25:3389-3402.

Annis, S. L., and Panaccione, D. G. 1998. Presence of peptide synthetase gene transcripts and accumulation of ergopeptines in Claviceps purpurea and Neotyphodium coenophialum. Can. J. Microbiol. 44:80-86.

Bailey, A. M., Kershaw, M. J., Hunt, B. A., Paterson, I. C., Charnley, K., Reynolds, S. E., and Clarkson, J. M. 1996. Cloning and sequence analysis of an intron-containing domain from a peptide synthetaseencoding gene of the entomopathogenic fungus Metarhizium anisopliae. Gene 173:195-197.

Ballance, D. J. 1991. Pages 1-29 in: Molecular Industrial Mycology. S. A. Leong and R. M. Berka, eds. Marcel Dekker, New York.

Bruchez, J. J. P., Eberle, J., and Russo, V. E. A. 1993. Regulatory sequences involved in the translation of Neurospora crassa mRNA: Kozak sequences and stop codons. Fungal Genet. Newsl. 40:85-88.

Diez, B., Gutierrez, S., Barredo, J. L., van Solingen, P., van der Voort, L. H., and Martin, J. F. 1990. The cluster of penicillin biosynthetic genes. Identification and characterization of the $p c b A B$ gene encoding the alpha-aminoadipyl-cysteinyl-valine synthetase and linkage to the $p c b C$ and penDE genes. J. Biol. Chem. 265:16358-16365.

Etchegaray, A., Dieckmann, R., Engel, P. C., Turner, G., and von Dohren, H. 1998. Group specific antibodies against the putative AMPbinding domain signature SGTTGXPKG in peptide synthetases and related enzymes. Biochem. Mol. Biol. Int. 44:235-243.

Filajdić, N., and Sutton, T. B. 1991. Identification and distribution of Alternaria mali on apples in North Carolina and susceptibility of different varieties of apples to Alternaria blotch. Plant Dis. 75:10451048.

Gocht, M., and Marahiel, M. A. 1994. Analysis of core sequences in the D-Phe activating domain of the multifunctional peptide synthetase TycA by site directed mutagenesis. J. Bacteriol. 176:2654-2662.

Gutiérrez, S., Diez, B., Montenegro, E., and Martin, J. F. 1991. Characterization of the Cephalosporium acremonium pcbAB gene encoding alpha-aminoadipyl-cysteinyl-valine synthetase, a large multidomain peptide synthetase: linkage to the $p c b C$ gene as a cluster of early cephalosporin biosynthetic genes and evidence of multiple functional domains. J. Bacteriol. 173:2354-2365.

Haese, A., Schubert, M., Herrmann, M., and Zocher, R. 1993. Molecular characterization of the enniatin synthetase gene encoding a multifunctional enzyme catalysing $N$-methyldepsipeptide formation in Fusarium scirpi. Mol. Microbiol. 7:905-914.

Hayami, C., Otani, H., Nishimura, S., and Kohmoto, K. 1982. Induced resistance in pear leaves by spore germination fluids of nonpathogens to Alternaria alternata Japanese pear pathotype and suppression of the induction by AK-toxin. J. Fac. Agric. Tottori Univ. 17:9.

Keller N. P., and Hohn, T. M. 1997. Metabolic pathway gene clusters in filamentous fungi. Fungal Genet. Biol. 21:17-29.

Kleinkauf, H., and von Dohren, H. 1987. Biosynthesis of peptide antibiotics. Annu. Rev. Microbiol. 41:259-289.

Kleinkauf, H., and von Dohren, H. 1990. Nonribosomal biosynthesis of peptide antibiotics. Eur. J. Biochem. 236:335-351.

Kohmoto, K., and Otani, H. 1991. Host recognition by toxigenic plant pathogens. Experientia 47:755-764.

Kohmoto, K., Taniguchi, T., and Nishimura, S. 1974. Correlation between the susceptibility of apple cultivars to Alternaria mali and their sensitivity to AM-toxin I. Ann. Phytopathol. Soc. Jpn. 43:65-66.

Kozak, M. 1991. Structural features in eukaryotic mRNAs that modulate the initiation of translation. J. Biol. Chem. 266:19867-19870.
Kuninaga, S., and Yokosawa, R. 1987. Studies on the taxonomy of plant pathogenic fungi by a comparison of DNA homology. I. Genetic relatedness among species in the genus Alternaria. (In Japanese). Ann. Phytopathol. Soc. Jpn. 53:368-369.

Kusaba, M., and Tsuge, T. 1994. Nuclear ribosomal DNA variation and pathogenic specialization in Alternaria fungi known to produce hostspecific toxins. Appl. Environ. Microbiol. 60:3055-3062.

Kusaba, M., and Tsuge, T. 1995. Phylogeny of Alternaria fungi known to produce host-specific toxins on the basis of variation in internal transcribed spacers of ribosomal DNA. Curr. Genet. 28:491-498.

Marahiel, M. A. 1992. Multidomain enzymes involved in peptide synthesis. FEBS Lett. 307:40-43.

Nikolskaya, A. N., Panaccione, D. G., and Walton, J. D. 1995. Identification of peptide synthetase-encoding genes from filamentous fungi producing host-selective phytotoxins or analogs. Gene 165:207-211.

Nishimura, S., and Kohmoto, K. 1983. Host-specific toxins and chemical structures from Alternaria species. Annu. Rev. Phytopathol. 21: 87-116.

Okuno, T., Ishita, Y., Sawai, K., and Matsumoto, T. 1974. Characterization of alternariolide, a host-specific toxin produced by Alternaria mali Roberts. Chem. Lett. 1974:635-638.

Otani, H., Kohmoto, K., and Kodama, M. 1995. Alternaria toxins and their effects on host plants. Can. J. Bot. 73(Suppl. 1):S453-S458.

Panaccione, D. G. 1996. Multiple families of peptide synthetase genes from ergopeptine-producing fungi. Mycol. Res. 100:429-436.

Park, P., Nishimura, S., Kohmoto, K., Otani, H., and Tsujimoto, K. 1981. Two action sites of AM-toxin I produced by apple pathotype of Alternaria alternata in host cells: an ultrastructural study. Can. J. Bot. 59: 301-310.

Park, P., Tsuda, M., Hayashi, Y., and Ueno, T. 1977. Effect of a hostspecific toxin (AM-toxin I) produced by Alternaria mali, an apple pathogen, on the ultrastructure of plasma membrane of cells in apple and Japanese pear leaves. Can. J. Bot. 55:2383-2393.

Pope, M. R., Ciuffetti, L. M., Knoche, H. W., McCrery, D. A., and Tomer, K. B. 1985. Structure of an amino acid analog of the hostspecific toxin from Helminthosporium carbonum. Biochemistry 22: 3502.

Pringle, R. B., and Scheffer, R. P. 1964. Host-specific plant toxins. Annu. Rev. Phytopathol. 2:133-156.

Punt, P. J., Oliver, R. P., Dingemanse, M. A., Pouwels, P. H., and van den Hondel, C. A. M. J. J. 1987. Transformation of Aspergillus based on the hygromycin B resistance marker from Escherichia coli. Gene $56: 117-124$.

Reed, K. C., and Mann, D. A. 1985. Rapid transfer of DNA from agarose gels to nylon membranes. Nucleic Acids Res. 13:7207-7221.

Sambrook, J., Fritsch, E. F., and Maniatis, T. A. 1989. Molecular Cloning: A Laboratory Manual. 2nd ed. Cold Spring Harbor Laboratory, Cold Spring Harbor, NY.

Sawamura, K. 1966. Studies on spotted disease of apples. 6. On the host-specific toxin of Alternaria mali Roberts. Bull. Hortic. Res. Stn. Japan, Ser. C. 4:43-59.

Scheffer, R. P., and Livingston, R. S. 1984. Host-selective toxins and their role in plant diseases. Science 223:415-419.

Scott-Craig, J. S., Panaccione, D. G., Pocard, J. A. and Walton, J. D. 1992. The cyclic peptide synthetase catalyzing HC-toxin production in the filamentous fungus Cochliobolus carbonum is encoded by a 15.7-kilobase open reading frame. J. Biol. Chem. 267:26044-26049.

Smith, D. J., Earl, A. J., and Turner, G. 1990. The multifunctional peptide synthetase performing the first step of penicillin biosynthesis in Penicillium chrysogenum is a 421073 protein similar to Bacillus brevis peptide antibiotic synthetases. EMBO J. 9:2743-2750.

Stachelhaus, T., and Marahiel, M. A. 1995a. Modular structure of genes encoding multifunctional peptide synthetases required for nonribosomal peptide synthesis. FEMS Microbiol. Lett. 125:3-14.

Stachelhaus, T., and Marahiel, M. A. 1995b. Modular structure of peptide synthetases revealed by dissection of the multifunctional enzyme GrsA. J. Biol. Chem. 270:6163-6169.

Stachelhaus, T., Mootz, H. D., and Marahiel, M. A. 1999. The specificity-conferring code of adenylation domains in nonribosomal peptide synthetases. Chem. Biol. 6:493-505.

Tanaka, A., Shiotani, H., Yamamoto, M., and Tsuge, T. 1999. Insertional mutagenesis and cloning of the genes required for biosynthesis of the host-specific AK-toxin in the Japanese pear pathotype of Alternaria alternata. Mol. Plant-Microbe Interact. 12:691-702. 
Thompson, J. D., Higgins, D. G., and Gibson, T. J. 1994. CLUSTAL W: Improving the sensitivity of progressive multiple sequence alignment through sequence weighting, position-specific gap penalties and weight matrix choice. Nucleic Acids Res. 22:4673-4680.

Tudzynski, P., Holter, K., Correia, T., Arntz, C., Grammel, N., and Keller, U. 1999. Evidence for an ergot alkaloid gene cluster in Claviceps purpurea. Mol. Gen. Genet. 261:133-141.

Turgay, K., Krause, M., and Marahiel, M. A. 1992. Four homologous domains in the primary structure of GrsB are related to domains in a super-family of adenylate-forming enzymes. Mol. Microbiol. 6:529546.

Turgay, K., and Marahiel, M. A. 1994. A general approach for identifying and cloning peptide synthetase genes. Peptide Res. 7:238-241.

Ueno, T., Nakashima, T., Uemoto, M., Fukami, H., Lee, S. N., and Izumiya, N. 1977. Mass spectrometry of Alternaria mali toxins and related cyclodepsipeptides. Biomed. Mass Spectrom. 4:134-142.

van Kan, J. A. L., van den Ackerveken, G. F. J. M., and de Wit, P. J. G. M. 1991. Cloning and characterization of cDNA of avirulence gene avr9 of the fungal pathogen Cladosporium fulvum, causal agent of tomato leaf mold. Mol. Plant-Microbe Interact. 4:52-59.

Walton, J. D. 1996. Host-selective toxins: Agents of compatibility. Plant Cell 8:1723-1733.
Walton, J. D., Earle, E. D., and Gibson, D. W. 1982. Purification and structure of the host-specific toxin from Helminthosporium carbonum race 1. Biochem. Biophys. Res. Commun. 107:785.

Walton, J. D., and Panaccione, D. G. 1993. Host-selective toxins and disease specificity: Perspective and progress. Annu. Rev. Phytopathol. 31:275-303.

Weber, G., Schörgendorfer, K., Schneider-Scherzer, E., and Leitner, E. 1994. The peptide synthetase catalyzing cyclosporine production in Tolypocladium niveum is encoded by a giant 45.8-kilobase open reading frame. Curr. Genet. 26:120-125.

Wolpert, T. J., Macko, V., Acklin, W., Jaun, B., Seibl, J., Meili, J., and Arigoni, D. 1985. Structure of victorin C, the major host-selective toxin from Cochliobolus victoriae. Experientia 41:1524.

Yang, G., Rose, M. S., Turgeon, B. G., and Yoder, O. C. 1996. A polyketide synthase is required for fungal virulence and production of the polyketide T-toxin. Plant Cell 8:2139-2150.

Yoder, O. C. 1980. Toxins in pathogenesis. Annu. Rev. Phytopathol. 18: 103-29.

Yoder, O. C., 1998. A mechanistic view of the fungal/plant interaction based on host-specific toxin studies. Pages 3-15 in: Molecular Genetics of Host-Specific Toxins in Plant Disease. K. Kohmoto and O. C. Yoder, eds. Kluwer Academic Pub., Dordrecht, The Netherlands. 